\title{
PEMILIHAN TEKNOLOGI STERILIZER PADA PABRIK KELAPA SAWIT MENGGUNAKAN METODE ANALYTICAL HIERARCHY PROCESS
}

\author{
SUBIYANTO \\ Pusat Audit Teknologi, Gedung Manajemen BPPT, Kawasan Puspiptek - Serpong, Tangerang Selatan-Banten 15314 \\ E-mail:biyan_to2003@yahoo.com
}

\begin{abstract}
ABSTRAK
Sejalan dengan peningkatan luas kebun sawit, jumlah pabrik pengolahan kelapa sawit (PKS) di Indonesia meningkat dari 205 unit tahun 1998 menjadi 695 unit tahun 2012. Teknologinya juga mengalami perkembangan (inovasi), dan salah satunya adalah alat rebusan (sterilizer) tandan buah segar (TBS), yaitu dari model horisontal ke vertikal, dan dari sistem batch ke kontinyu. Kajian ini menganalisis penetapan prioritas (priority setting) dalam pemilihan teknologi rebusan TBS yang sesuai dengan tujuan pengguna, dengan menggunakan metode Analytical Hierarchy Process (AHP). Metode AHP digunakan karena mudah dipahami dan mampu menyederhanakan persoalan komplek ke dalam struktur keputusan yang sederhana. Dari tiga jenis produk teknologi yang dianalisis, hasilnya menunjukkan bahwa urutan prioritasnya adalah sterilizer model vertikal dengan tingkat prioritas 0,366 , kemudian diikuti dengan model horisontal $(0,335)$ dan model kontinyu $(0,299)$.
\end{abstract}

Kata Kunci: penentuan prioritas, sterilizer, pabrik kelapa sawit, metode AHP

\begin{abstract}
In Indonesia, the increasing area of palm oil plantation has been followed by the increasing number of palm oil mills from 205 units in 1998 to 695 units in 2012. The palm oil mill technology has also been developed, and one of them is fresh bunch sterilizer. The technology of sterilizer changed from horizontal to vertical, and the system improved from batch to continuous. This study analyze the determination of priority in selecting sterilizer technology by using Analytical Hierarchy Process (AHP) method. The advantages of AHP method are easy to understand and useful for decomposing a complex problems into a simple hierarchy of decision problem. According to the evaluation of three alternatives by using AHP, it shows that the priority order of the sterilizer models is respectively vertical, horizontal, and continuous with overall weight 0.366, 0.335 , and 0.299 respectively.
\end{abstract}

Keywords : priority determination, sterilizer, palm oil mills, AHP

\section{PENDAHULUAN}

\section{Latar Belakang}

Kelapa sawit merupakan komoditas yang pertumbuhannya paling pesat di antara komoditas perkebunan lainnya di Indonesia. Pada periode 1995-2009, produksi CPO tumbuh ratarata $13 \%$ per tahun, dari 4,48 juta ton tahun 1995 menjadi 19,5 juta ton tahun 2009 (Oil World, 2010). Indonesia Commodity and Derivatives Exchange (ICDX) melaporkan bahwa dengan produksi CPO sekitar 23,5 juta ton pada tahun 2011, Indonesia menjadi produsen CPO nomor satu dunia dengan pangsa sekitar 46\% (Bisnis Indonesia, 2011). Fadli Hasan (2014) dari Gabungan Pengusaha Kelapa Sawit Indonesia (GAPKI) melaporkan bahwa produksi CPO tahun 2012 mencapai 26,5 juta ton, sedangkan pada tahun 2013 diprediksi mencapai 26 juta ton atau turun $1,9 \%$ dibandingkan tahun 2012.

Seiring dengan kenaikan produksi CPO, jumlah Pabrik Kelapa Sawit (PKS) juga meningkat dari 205 unit tahun 1998 menjadi 320 unit tahun 2004, dan 477 unit tahun 2006, atau naik sekitar 13\% per tahun (DMSI, 2008). 
Ditjen Perkebunan (2012) melaporkan bahwa pada tahun 2010, jumlah PKS telah mencapai 608 unit dengan total kapasitas sebesar 34.284 ton TBS/jam, sementara Creative Data Make Investigation \& Research (CDMI) Consulting Group melaporkan bahwa jumlah PKS nasional pada tahun 2012 sebanyak 695 unit dan tahun 2013 diperkirakan menjadi 713 unit dengan total kapasitas 34.628 ton TBS/jam (CDMI, 2014).

Perkembangan jumlah PKS juga diikuti dengan peningkatan teknologi. Pada tahun 1998, kapasitas olah rata-rata per unit PKS sekitar 39 ton TBS/jam, kemudian pada tahun 2004 meningkat menjadi 42 ton TBS/jam, dan pada tahun 2010 menjadi sekitar 56 ton TBS/jam, atau tumbuh sekitar $4 \%$ per tahun (Subiyanto, 2011). Teknologi prosesnya juga telah mulai bergeser dari semula sistem batch mengarah ke kontinyu.

Dalam proses pengolahan kelapa sawit, salah satu tahapan yang paling penting adalah perebusan tandan buah segar (TBS) atau sterilisasi, karena sangat menentukan jumlah (rendemen) dan kualitas minyak (CPO) yang dihasilkan. Secara teknis, perebusan TBS dilakukan pada bejana bertekanan (sterilizer) dengan menggunakan steam. Menurut Pahan (2007), perebusan TBS bertujuan untuk memudahkan pelepasan berondolan dari janjangan, mematikan aktivitas enzim penstimulir kenaikan asam lemak bebas, memudahkan pemisahan daging buah dari biji, mempermudah proses pemisahan molekul minyak dari daging buah, serta menurunkan kadar air dan merupakan proses pengeringan awal terhadap biji. Saat ini di Indonesia terdapat tiga alternatif teknologi sterilizer, yaitu model horisontal, vertikal, dan kontinyu. Sampai dengan pertengahan dekade 2000 - 2010, perebusan TBS semua PKS di Indonesia masih menggunakan sterilizer model horisontal. Setelah itu mulai dikenalkan teknologi sterilizer model vertikal. Kedua model ini bekerja dengan sistem batch. Terakhir muncul sterilizer yang bekerja secara kontinyu, yang diintroduksi dari Malaysia.
Permasalahannya, sarana, sistem dan efisiensi kerja, serta keekonomian ketiga jenis teknologi berbeda, dan setiap produsen/vendor alat mengklaim kelebihan dari produknya masing-masing. Di lain pihak, PKS sebagai pengguna teknologi menginginkan sterilizer yang terbaik karena perannya yang sangat vital dalam proses pengolahan CPO. Selama ini, pemilihan teknologi yang dilakukan oleh manajemen PKS umumnya menggunakan pendekatan pragmatis, yaitu dengan melihat apa yang telah dilakukan oleh PKS lain. Studi ini dimaksudkan untuk mendiskusikan metode pemilihan teknologi sterilizer yang lebih ilmiah dan komprehensif, dengan tujuan menghitung peringkat prioritas (priority setting) atas ketiga jenis teknologi sterilisasi tersebut.

\section{METODE}

\section{Urgensi Penggunaan AHP}

Analisis prioritas dalam studi ini menggunakan model Multi-Criteria Decision Making (MCDM) yang diaplikasikan ke dalam metode Analytical Hierarchy Process (AHP) yang dikembangkan oleh Saaty (1993). Metode AHP dipilih dengan pertimbangan bahwa keputusan pemilihan teknologi (sterilizer) merupakan bagian dari rencana strategis perusahaan, dan dasar keputusannya melibatkan beberapa kriteria yang terukur maupun tidak terukur (tangible and intangible). Di lain pihak, di antara keandalan metode AHP adalah fleksibilitasnya dalam mengakomodasi data dan informasi, baik yang bersifat kuantitatif (terukur) maupun kualitatif (tidak terukur). Selama ini pemilihan teknologi yang dilakukan oleh perusahaan pada umumnya lebih banyak menggunakan parameter ekonomi, dengan dukungan data yang bersifat kuantitatif. Persaingan bisnis semakin ketat, sehingga diperlukan penyelarasan antara strategi teknologi dengan strategi bisnis jangka panjang. Karena itu penentuan jenis teknologi tidak cukup hanya didasarkan kepada parameter ekonomi saja, dan AHP menjadi pilihan tool yang dapat mendukung 
penyelarasan antara strategi teknologi dan strategi bisnis tersebut (Ahmadabadi et al., 2013, Moreno-Jiménez et al., 2012).

Analisis pemilihan teknologi menggunakan metode AHP sudah banyak dilakukan di luar negeri, seperti yang dilakukan oleh Montenegro et al. (2013) di bidang teknologi industri kakao, Kim (2012) dibidang teknologi informasi, Abu Samah et al. (2011) di bidang teknologi lingkungan, dan AlHawari et al. (2011) di bidang teknologi elektronik. Di dalam negeri, penggunaan metode AHP untuk mengevaluasi efisiensi teknologi gas buang rumah tangga ramah lingkungan juga dilakukan oleh Moengin (2013). Penggunaan metode AHP dalam industri kelapa sawit sudah dilakukan oleh beberapa peneliti dengan tujuan aplikasi yang berbeda-beda, tetapi belum ada yang bertujuan untuk pemilihan teknologi. Fibrian dkk. (2011) menggunakan metode AHP untuk menganalisis optimasi pemanfaatan tandan kosong (limbah) kelapa sawit, sementara Hidayat dkk. (2012) dan Hadiguna (2012) menggunakannya untuk menilai kinerja rantai pasok pada industri kelapa sawit.

\section{Pendekatan Analisis}

Analisis dalam kajian ini menggunakan kriteria teknis-teknologi dan bisnis. Kriteria teknis-teknologi dimaksudkan untuk melihat kebutuhan, persyaratan teknologi, dan kendala operasional yang dihadapi pengelola PKS untuk masing-masing model teknologi sterilisasi, serta kaitannya dengan kualitas dan kuantitas produk/ output yang dihasilkan. Sementara kriteria bisnis dimaksudkan untuk melihat prospek ketiga jenis teknologi dari sisi biaya-manfaat, serta pertimbangan strategis lain yang terkait bagi kelangsungan usaha.

Data teknis-teknologi untuk ketiga jenis produk teknologi sterilizer dikumpulkan dari hasil survey pada 3 unit PKS di Sumatera Utara yang dikelola BUMN dan 1 unit PKS swasta di Riau. Survey dilakukan pada bulan PebruariJuni 2012. Sedangkan data dan informasi terkait manajemen dan bisnis dikumpulkan dari hasil diskusi panel dengan manajemen perusahaan pengelola PKS yang sedang merencanakan membangun/menambah PKS baru. Panelis terdiri dari 9 orang praktisi yang juga merepresentasikan expert (di bidang teknik, manajemen, dan bisnis) dan dibantu oleh 2 orang tenaga ahli yang sekaligus menjadi fasilitator penerapan metode AHP. Beberapa data teknis lainnya bersumber dari prospektus pabrikan alat dan data sekunder.

\section{Model Analisis}

Diagram alir aplikasi metode AHP ditunjukkan pada Gambar 1. Prinsip-prinsip yang digunakan dalam penerapan metode AHP menurut Saaty (1993) dan Saaty (2008) meliput: (a) pemecahan/ penyederhanaan masalah (decomposition), (b) penilaian perbandingan (comparative judgment), (c) konsistensi yang logis (logical consistency), dan (d). sintesa prioritas (synthesis of priority). Penjelasan lanjutan tentang prinsip AHP disampaikan pada uraian berikut.

\section{Penyederhanaan Permasalahan}

Penyederhanaan permasalahan (pemilihan teknologi sterilizer) dilakukan dengan membuat struktur permasalahan sedemikian rupa sehingga sistematis dan realitasnya mudah dipahami. Caranya dengan melakukan decomposition, yaitu memecah realitas yang melingkupi ke dalam beberapa gugusan yang homogen (dapat dibandingkan), dan membagi lagi gugusan ini menjadi gugusan-gugusan yang lebih kecil sehingga terbentuk suatu gambaran dalam bentuk hirarki yang lengkap. Langkah ini dilakukan untuk memperoleh pengetahuan dari kasus yang dibahas secara lebih rinci serta untuk menjelaskan hubungan atau keterkaitan dari masing-masing gugusan tersebut, baik secara horisontal maupun vertikal. Karena itu hirarki yang dihasilkan disebut dengan struktur keputusan.

\section{Penilaian Perbandingan}

Penilaian perbandingan (Comparative Judgment) yaitu membandingkan setiap elemen dengan elemen lainnya pada setiap tingkat hirarki secara berpasangan sehingga diperoleh 


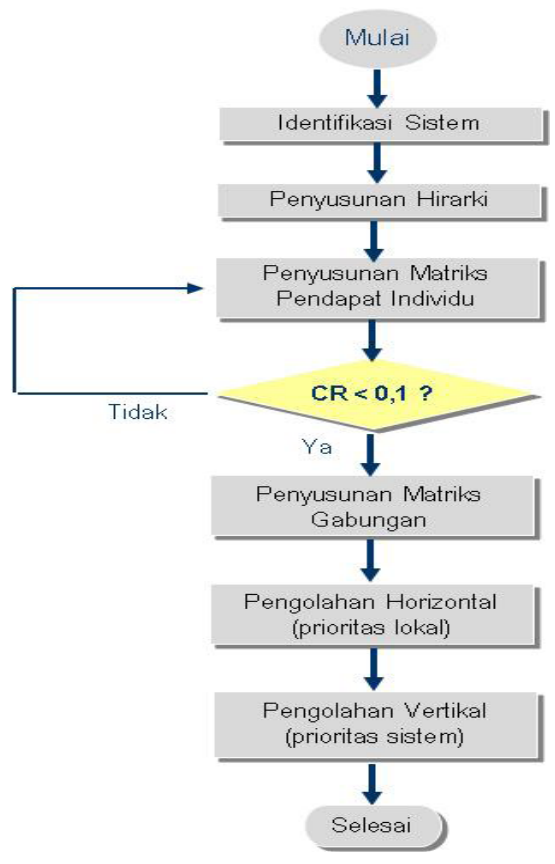

Gambar 1. Diagram alir aplikasi metode AHP

nilai tingkat kepentingan relatif elemen dalam kontribusinya terhadap setiap elemen yang ada pada hirarki di atasnya. Karena data yang dibandingkan satuan dan intensitasnya beragam, maka kuantifikasi penilaian dilakukan dengan menggunakan skala komparasi sebagaimana ditunjukkan pada Tabel 1 .

Perbandingan berpasangan (pairwise comparison) disusun dalam format matriks. Dalam format matematik, jika Z1, Z2, ..., Zn adalah set elemen, maka kuantifikasi penilaian pada pasangan elemen itu akan membentuk matriks $\mathrm{n} \times \mathrm{n}$ :

$A=\left(a_{i j}\right) ;(i, j=1,2, \ldots, n)$, di mana $a_{i j}$ memenuhi aturan sebagai berikut :

- Jika $\mathrm{a}_{\mathrm{ij}}=\alpha$, maka $\mathrm{a}_{\mathrm{ji}}=1 / \alpha ; \alpha \neq 0$

- Jika Zi dinilai relatif sama dengan Zj, maka aij $=1$; aji $=1$; dan aii $=1$ untuk semua i;

$$
A=\left|\begin{array}{cccc}
1 & a_{12} & \ldots \ldots \ldots & a_{1 n} \\
1 / a_{12} & 1 & \ldots \ldots \ldots . & a_{2 n} \\
\cdot & & \ldots \ldots . & . \\
. & & \ldots \ldots . & . \\
1 / a_{1 n} & 1 / a_{2 n} & \ldots \ldots \ldots & 1
\end{array}\right|
$$

Jika penilaian perbandingan berpasangan dilakukan secara voting (mandiri) oleh masingmasing penilai, maka hasil penilaian individu

Tabel 1. Skala komparasi dalam perbandingan berpasangan

\begin{tabular}{|c|c|c|}
\hline $\begin{array}{c}\text { Tingkat } \\
\text { kepen-tingan }\end{array}$ & Definisi & Penjelasan \\
\hline 1 & Sama pentingnya & $\begin{array}{l}\text { Kedua elemen memberikan kontribusi yang sama besarnya } \\
\text { kepada tujuan yang dikehendaki }\end{array}$ \\
\hline 3 & Sedikit lebih penting & $\begin{array}{l}\text { Pengalaman cenderung mengarah sedikit pada satu elemen } \\
\text { yang disukai dibanding dengan elemen lainnya }\end{array}$ \\
\hline 5 & Jelas lebih penting & $\begin{array}{l}\text { Pengalaman lebih kuat kecenderungannya memenangkan satu } \\
\text { elemen dengan kuat }\end{array}$ \\
\hline 7 & $\begin{array}{l}\text { Sangat jelas lebih } \\
\text { penting }\end{array}$ & $\begin{array}{l}\text { Pengalaman menunjukkan dominasi satu elemen terhadap } \\
\text { elemen lainnya }\end{array}$ \\
\hline 9 & $\begin{array}{l}\text { Pasti/mutlak lebih } \\
\text { penting }\end{array}$ & $\begin{array}{l}\text { Petunjuk yang ada menegaskan dominasi satu elemen terhadap } \\
\text { elemen lainnya, dengan tanpa keraguan lagi }\end{array}$ \\
\hline $2,4,6,8$ & $\begin{array}{l}\text { Apabila ragu-ragu } \\
\text { antara dua nilai yang } \\
\text { berdekatan }\end{array}$ & $\begin{array}{l}\text { Seringkali diperlukan suatu interpolasi penilaian kompromi } \\
\text { secara numeric }\end{array}$ \\
\hline $1 /(1-9)$ & $\begin{array}{l}\text { Kebalikan nilai } \\
\text { tingkat kepenting-an } \\
\text { dari skala 1-9 }\end{array}$ & Asumsi yang masuk akal \\
\hline
\end{tabular}

Sumber : Saaty (1993) 
harus diolah dulu ke dalam matriks pendapat gabungan. Pada studi ini karena penilaian dilakukan secara konsensus, maka tidak diperlukan pengolahan pendapat gabungan, karena pendapat yang muncul sudah merupakan pendapat gabungan dari para penilai.

\section{Konsistensi yang logis}

Perbandingan berpasangan harus dilakukan secara konsisten. Contohnya, jika harga sterilizer model horisontal 30\% lebih murah dari model vertikal dan model vertikal $30 \%$ lebih murah dari model kontinyu, maka model horisontal seharusnya lebih murah sekitar 50\% dari model kontinyu. Jika model horisontal hanya $30 \%$ lebih murah dari model kontinyu, maka penilaiannya tidak konsisten. Penilaian dilakukan oleh para ahli yang kompeten (experts), dan dalam studi ini ditempuh melalui mekanisme konsensus. Suatu penilaian perbandingan berpasangan dikatakan memenuhi persyaratan jika Consistency Ratio
(CR) $\leq$ 0,1. Jika CR > 0,1 maka harus dilakukan penilaian ulang, sampai dipenuhi persyaratan $\mathrm{CR}$ $\leq 0,1$.

\section{Sintesa Prioritas}

Sintesa prioritas (Synthesis of Priority) dimaksudkan untuk menyusun prioritas elemen-elemen keputusan pada berdasarkan kepada hirarki yang ada. Sintesa dilakukan secara horisontal dan vertikal. Sintesa awal dilakukan secara horisontal dengan tujuan untuk menghitung tingkat prioritas setiap elemen pada setiap hirarki, dan hasilnya disebut dengan prioritas lokal.

Tiap hirarki keputusan mempengaruhi faktor puncak (tujuan akhir) dengan intensitas yang berbeda. Karena itu sintesa prioritas terakhir adalah dengan melakukan pengolahan vertikal. Pengolahan vertikal dimaksudkan untuk menyusun prioritas pengaruh setiap elemen pada tingkat hirarki keputusan tertentu terhadap

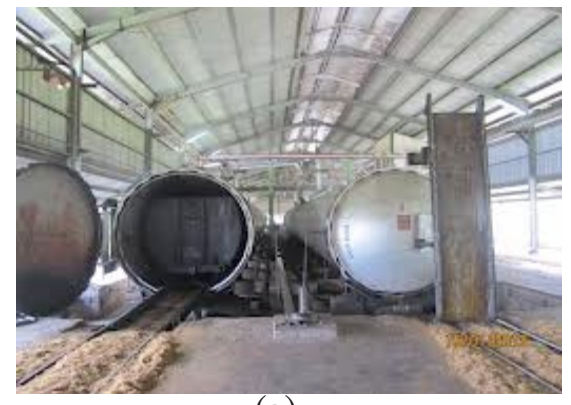

(a)

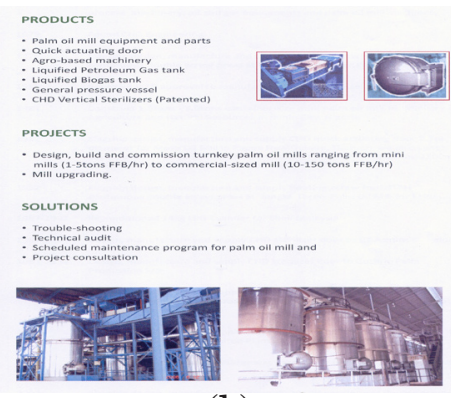

(b)

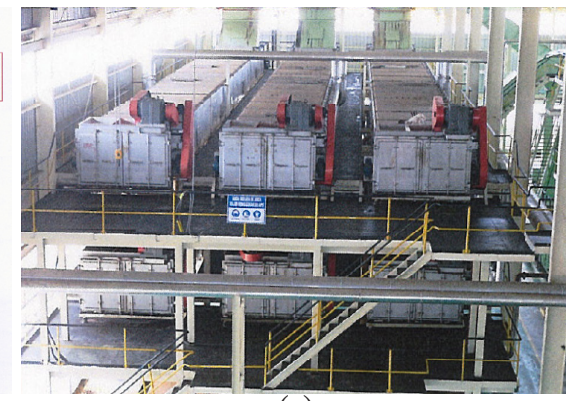

(c)

Gambar 2. (a) Sterilizer horisontal, (b)vertikal, dan (c) kontinyu

Tabel 2. Perbandingan sistem teknologi sterilizer

\begin{tabular}{|c|c|c|c|c|}
\hline \multirow{2}{*}{\multicolumn{2}{|c|}{$\begin{array}{l}\text { Parameter } \\
\text { Teknologi }\end{array}$}} & \multicolumn{3}{|c|}{ Sistem teknologi sterilizer } \\
\hline & & Horisontal & Vertikal & Kontinyu \\
\hline 1. & $\begin{array}{l}\text { Kebutuhan area } \\
\text { instalasi alat }\end{array}$ & besar $( \pm 4000 \mathrm{~m} 2)$ & $\operatorname{kecil}( \pm 500 \mathrm{~m} 2)$ & sedang $(600-1000 \mathrm{~m} 2)$ \\
\hline 2. & $\begin{array}{l}\text { Sistem kerja/ } \\
\text { kontinyuitas } \\
\text { proses }\end{array}$ & batch & $\begin{array}{l}\text { batch tapi dibantu } \\
\text { dengan alat semi } \\
\text { otomatis }\end{array}$ & kontinyu \\
\hline
\end{tabular}


3. Alat angkut buah lori dan tracknya conveyor conveyor

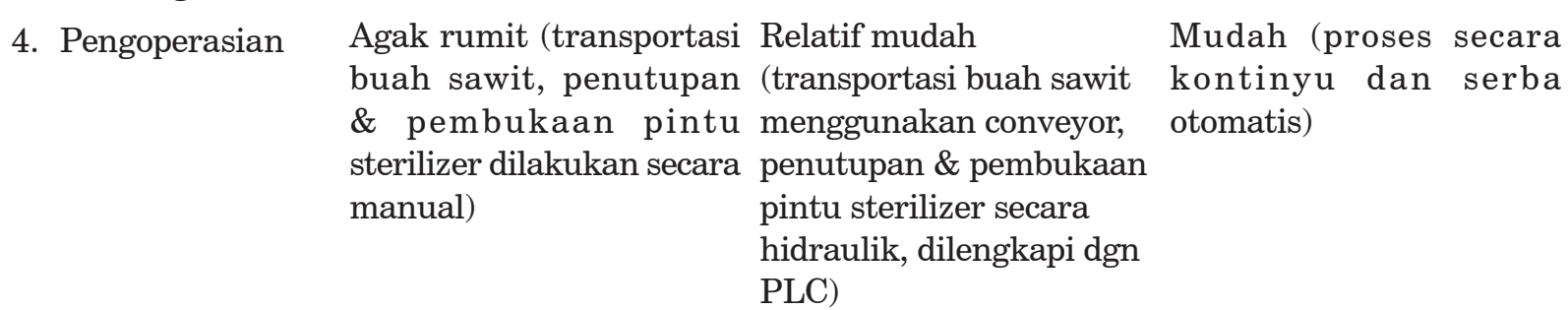

5. Jumlah operator banyak (14 orang) sedang (4 orang) sedikit (1 orang pengawas/ tidak secara khusus mengoperasikan sterilizer karena prosesnya kontinyu)

tanpa puncak (datar dari awal-akhir rebusan)

6. Sistem perebusan 3 puncak tekanan steam 1-2 puncak tekanan steam (peak)

1 bar

7. Tekan (peak)

3 bar

8. Safety

kurang (area kerja licin sedang (bejana

baik (keterlibatan orang karena ceceran minyak, bertekanan tinggi dengan risiko tersabet kawat frekuensi lebih rendah) penarik lori yg putus, benda berat/lori jatuh dari crane, bejana bertekanan tinggi/ meledak)

9. Perawatan mudah, tapi mahal mudah (penggantian (penggantian lori secara rantai conveyor, dan bisa berkala) dilakukan sendiri)

sukar dan mahal (penggantian rantai conveyor, dimana bahan dan teknisi masih impor)

Sumber: Sia (2009), Awan (2012), CHD Engineering (2009), serta hasil wawancara dan observasi lapangan

sasaran utama, dan hasilnya disebut dengan prioritas global. Sintesa prioritas horisontal dan vertikal dalam studi ini dilakukan dengan bantuan software Criterium Desicion Plus.

\section{HASIL DAN PEMBAHASAN}

\section{Deskripsi Teknologi Sterilizer}

Proses sterilisasi TBS membutuhkan energi (steam) bertekanan dan menuntut keterandalan alat. Ketidaktepatan dalam penyediaan dan pendistribusian steam yang sesuai dengan kebutuhan akan berpengaruh kepada pemborosan energi serta tidak meratanya perebusan, yang pada akhirnya berpengaruh kepada biaya sterilisasi, tingkat rendemen, kapasitas olah, serta kualitas CPO yang dihasilkan. Perbandingan teknologi sterilizer model horisontal, vertikal, dan kontinyu secara fisik ditunjukkan pada Gambar 2, sedangkan deskripsi singkat tentang sistem dan teknologinya disampaikan pada Tabel 2 .

\section{Pengolahan Data dan Analisis Perumusan Kriteria dan Hirarki}

Tujuan akhir (ultimate goal) pada studi ini adalah memilih teknologi sterilizer yang mampu memberikan nilai manfaat terbesar untuk kelangsungan bisnis. Dengan demikian hirarki yang paling atas (hirarki I) dari analisis AHP ini adalah mencari teknologi sterilizer yang ideal. Alternatif teknologi sterilizer yang akan dipilih adalah : (1) model horisontal, (2) model vertikal, dan (3) model kontinyu. Dengan pertimbangan 
bahwa pemilihan teknologi merupakan bagian dari perencanaan strategis perusahaan, maka pada hirarki II dibentuk kriteria yang berpengaruh kepada tujuan akhir, yang terdiri dari elemen: (1) performa alat, (2) keuangan, dan (3) image teknologi.

Perfoma alat merupakan indikator keandalan dan efektivitas kerja alat yang datanya relatif objektif dan pasti. Karena itu elemen ini dianggap merupakan kriteria utama yang harus menjadi pertimbangan dalam memilih teknologi. Keandalan dan efektivitas alat tersebut selanjutnya dijabarkan lagi ke dalam bentuk indikator atau sub kriteria yang data dan informasinya mudah diperoleh. Karena itu pada hirarki III di bawah elemen performa alat, disusun sub kriteria yang terdiri dari elemen yang relevan dengan performa alat, yaitu : (1.1) efisiensi alat, (1.2) produk yang dihasilkan, dan (1.3) kepraktisan alat (kemudahan pengoperasian \& perawatan).
Kriteria performa alat harus diimbangi dengan kriteria keuangan untuk tujuan bisnis. Artinya, pemilihan teknologi perlu mempertimbangkan realita kemampuan perusahaan dalam menyediakan dana investasi untuk pengadaan alat, biaya operasional yang murah, dan kalkulasi tingkat pengembalian modal atas investasi yang dikeluarkan. Untuk pemodelan analisa, kriteria keuangan ini selanjutnya dijabarkan lagi ke dalam sub kriteria (hirarki III) dalam bentuk indikator terukur yang terdiri dari elemen : (2.1) nilai investasi atau harga alat (2.2) biaya operasional, dan (2.3) tingkat pengembalian investasi (internal rate of return $=I R R$ ).

Pemain industri CPO semakin banyak sehingga kompetisi semakin meningkat. Bagi perusahaan yang memiliki perhatian terhadap nilai kompetisi, image perusahaan menjadi kebutuhan. Karena itu image teknologi perlu dipertimbangkan sebagai kriteria dalam

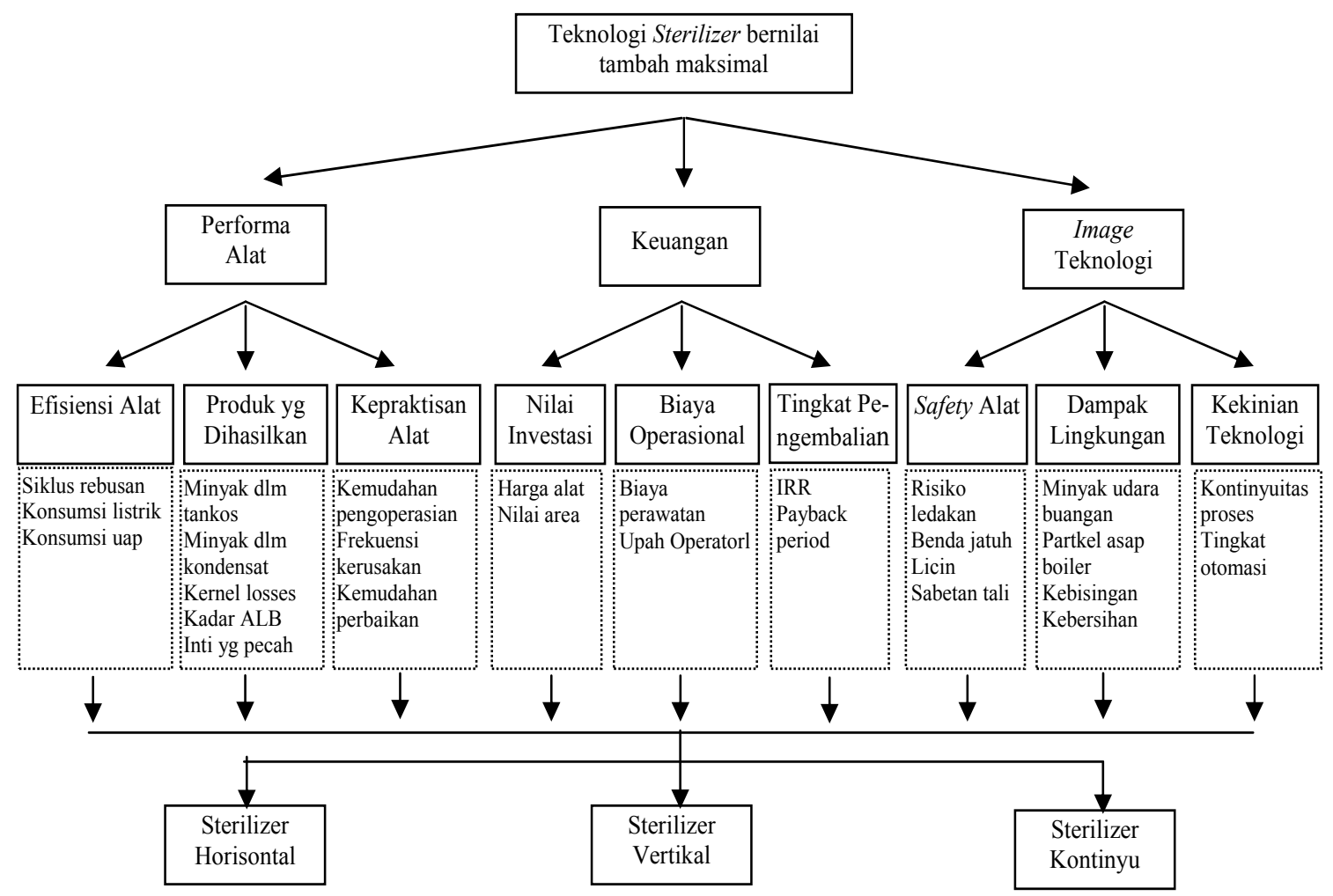

Gambar 3. Struktur hirarki keputusan pemilihan teknologi sterilizer 
Tabel 3. Matriks perbandingan hirarki II

\begin{tabular}{cccc}
\hline $\begin{array}{c}\text { Tujuan } \\
\text { (UG) }\end{array}$ & $\begin{array}{c}\text { Performa } \\
\text { Alat (PA) }\end{array}$ & $\begin{array}{c}\text { Keuang an } \\
\text { (KU) }\end{array}$ & $\begin{array}{c}\text { Image Tekn } \\
\text { (IT) }\end{array}$ \\
\hline $\mathrm{PA}$ & 1 & 2 & 5 \\
$\mathrm{KU}$ & $1 / 2$ & 1 & 3 \\
$\mathrm{IT}$ & $1 / 5$ & $1 / 3$ & 1 \\
\hline
\end{tabular}

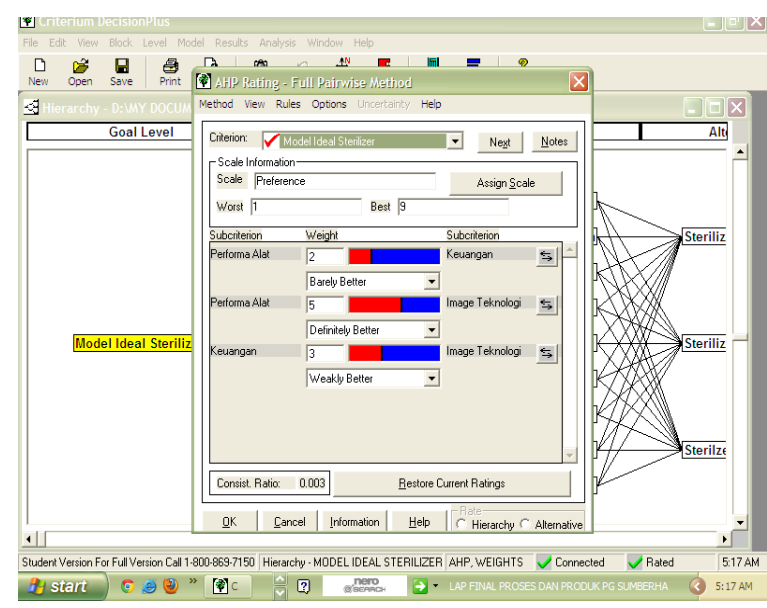

Gambar 4. Perbandingan berpasangan hirarki II

pemilihan teknologi, walaupun bobotnya tidak sebesar kriteria performa teknologi dan keuangan. Agar penilaiannya objektif dan terukur, kriteria image teknologi pada hirarki II dijabarkan ke dalam sub kriteria yang terdiri dari elemen : (3.1) keselamatan (safety), (3.2) dampak lingkungan, dan (3.3) kekinian teknologi. Hasil penelitian Radjagukguk (2009) menunjukkan bahwa kecelakaan kerja terbesar (53\%) pada pengoperasian PKS horisontal terdapat pada operator sterilizer.

Berdasarkan deskripsi tujuan akhir, kriteria, dan sub kriteria, serta alternatif teknologi yang akan dipilih, maka secara keseluruhan struktur hirarki keputusan yang terbentuk adalah seperti pada Gambar 3. Variabel dalam kotak garis putus-putus menunjukkan indikator proxy untuk elemen hirarki III agar pembandingan lebih terukur.

\section{Perbandingan Berpasangan Hirarki II}

Karena hirarki I merupakan jenjang puncak yang menggambarkan tujuan akhir dari analisis yaitu untuk mendapatkan model alat sterilizer yang ideal (mampu memberikan nilai manfaat terbesar untuk kelangsungan bisnis), maka penilaian (perbandingan tingkat prioritas elemen) dimulai pada hirarki II. Pada hirarki II, tingkat kepentingan relatif atau tingkat prioritas dari tiga elemen yang ada untuk mendukung tujuan pemilihan alat sterilizer yang memberikan nilai tambah maksimal dibandingkan satu sama lain secara berpasangan (pairwise comparison). Untuk mendapatkan penilaian yang objektif dan berkualitas, penilaian perbandingan dilakukan melalui forum diskusi panel yang terdiri dari pihak-pihak yang kompeten di bidang bisnis, keteknikan, dan operasional produksi.

Hasil penilaian panel menggunakan skala komparasi berdasarkan Tabel 1 untuk hirarki II seperti ditunjukkan pada Tabel 3. Penilaian matriks berpasangan dan pengolahan data dalam studi ini dilakukan menggunakan software dan contoh prosesnya ditunjukkan pada Gambar 4. Hasil perhitungan komputer menunjukkan bahwa dengan nilai perbandingan seperti pada Tabel 3 , diperoleh Consistency Ratio (CR) sebesar 0,003, yang berarti bahwa penilaian telah dilakukan secara konsisten $(\mathrm{CR}<0,1)$, sehingga memenuhi syarat untuk pengolahan lanjutan.

\section{Hirarki III}

Karena hirarki II merupakan hirarki tidak lengkap (tidak semua sub kriteria di jenjang bawahnya mempunyai hubungan langsung, misal kriteria performa alat tidak mempunyai hubungan langsung dengan sub kriteria nilai investasi), maka perbandingan pada hirarki III dilakukan hanya terhadap sub kriteria yang mempunyai hubungan langsung yang sama dengan elemen di atasnya (hirarki II). Sesuai struktur hirarki pada Gambar 3, penilaian perbandingan antar 
sub kriteria pada hirarki III dilakukan sebagai berikut :

- Pada kriteria performa alat, sub kriteria efisiensi alat, produk yang dihasilkan, dan kepraktisan alat dibandingkan tingkat kepentingannya secara berpasangan;

- Cara penilaian yang sama berlaku untuk kriteria keuangan dan image teknologi.

Tabel 4. Efisiensi menurut jenis sterilizer

\begin{tabular}{lccc}
\hline $\begin{array}{c}\text { Sub-kriteria } \\
\text { efisiensi } \\
\text { teknologi }\end{array}$ & $\begin{array}{c}\text { Horisontal } \\
\text { (H) }\end{array}$ & $\begin{array}{c}\text { Vertikal } \\
\text { (V) }\end{array}$ & $\begin{array}{c}\text { Kontinyu } \\
\text { (K) }\end{array}$ \\
\hline $\begin{array}{l}\text { Siklus rebusan } \\
\text { (menit/siklus) }\end{array}$ & $95-110$ & $90-100$ & $80-90$ \\
$\begin{array}{l}\text { Konsumsi } \\
\text { listrik (Kwh/ }\end{array}$ & $15-17$ & $16-18$ & $18-20$ \\
ton TBS) & & & \\
$\begin{array}{l}\text { Konsumsi uap } \\
\text { (kg/ton TBS) }\end{array}$ & $600-700$ & $300-400$ & $540-560$ \\
\hline
\end{tabular}

Sumber : PTPN IV (2010); Pahan (2007); CHD (2009); dan Hasil Survey

\section{Hirarki IV}

Pada hirarki IV, penilaian dilakukan dengan menghitung performansi relatif dari masingmasing model sterilizer, dari sudut pandang sub kriteria yang ada pada hirarki III. Karena jumlah sub kriteria pada hirarki III ada sembilan dan hirarkinya berbentuk lengkap, maka ada sembilan set pairwise comparison. Sub kriteria pada hirarki III dijabarkan ke dalam bentuk "indikator proxy" yang dinilai mewakili sub kriteria yang bersangkutan agar pembandingan elemen hirarki IV lebih terukur. Indikator proxy ini merupakan fakta alat yang sebagian besar terukur, atau secara faktual di lapangan derajatnya dapat dibedakan. Indikator proxy untuk masing-masing elemen III ditunjukkan pada Gambar 3 (dan Tabel 5).

Penilaian performansi alternatif berdasarkan sub kriteria efisiensi teknologi hirarki ditunjukkan pada Tabel 4. Elemen efisiensi teknologi diwakili

Tabel 5. Perbandingan performansi masing-masing sterilizer pada hirarki IV

\begin{tabular}{|c|c|c|c|c|c|c|}
\hline No & Sub-kriteria & Indikator Proxy & $\begin{array}{c}\text { Bobot } \\
\text { Indikator* }\end{array}$ & $\mathbf{H}$ & $\mathbf{V}$ & $\mathbf{K}$ \\
\hline (1) & (2) & (3) & (4) & (5) & (6) & (7) \\
\hline \multirow[t]{4}{*}{1} & \multirow[t]{4}{*}{ Efisiensi Alat } & Siklus perebusan (menit) & 0,33 & 3 & 2 & 1 \\
\hline & & Konsumsi listrik/ton TBS (KWH) & 0,33 & 1 & 2 & 4 \\
\hline & & Konsumsi uap/ton TBS (kg) & 0,34 & 6 & 1 & 3 \\
\hline & & Penilaian akhir & 1,00 & 6 & 1 & 3 \\
\hline \multirow[t]{6}{*}{2} & \multirow{6}{*}{$\begin{array}{l}\text { Produk yang } \\
\text { Dihasilkan }\end{array}$} & Kehilangan minyak dalam tandan kosong $(\%)$ & 0,40 & 1 & 3 & 3 \\
\hline & & Kehilangan minyak dalam air kondensat (\%) & 0,30 & 3 & 5 & 1 \\
\hline & & Kehilangan Kernel (\%) & 0,10 & 3 & 3 & 3 \\
\hline & & Kualitas CPO (\% ALB) & 0,10 & 3 & 5 & 2 \\
\hline & & Kualitas Kernel (\% inti pecah) & 0,10 & 3 & 3 & 5 \\
\hline & & Penilaian akhir & 1,00 & 1 & 4 & 2 \\
\hline \multirow[t]{4}{*}{3} & Kepraktisan Alat & Kemudahan pengoperasian & 0,40 & 6 & 2 & 1 \\
\hline & & Frekuensi kerusakan alat & 0,20 & 1 & 1 & 3 \\
\hline & & Tingkat kesulitan perbaikan & 0,40 & 1 & 2 & 5 \\
\hline & & Penilaian akhir & 1,00 & 3 & 1 & 3 \\
\hline
\end{tabular}




\begin{tabular}{|c|c|c|c|c|c|c|}
\hline \multirow[t]{3}{*}{4} & \multirow[t]{3}{*}{ Nilai Investasi } & Nilai pengadaan alat $(\mathrm{Rp})$ & 0,95 & 1 & 2 & 4 \\
\hline & & Nilai area stasiun rebusan $(\mathrm{Rp})$ & 0,05 & 6 & 1 & 1 \\
\hline & & Penilaian akhir & 1,00 & 1 & 3 & 5 \\
\hline \multirow[t]{3}{*}{5} & \multirow{3}{*}{$\begin{array}{l}\text { Biaya } \\
\text { Operasional }\end{array}$} & Biaya perawatan alat (Rp) & 0,50 & 6 & 2 & 4 \\
\hline & & Beban upah SDM pabrik (Rp) & 0,50 & 6 & 3 & 1 \\
\hline & & Penilaian akhir & 1,00 & 3 & 1 & 1 \\
\hline \multirow[t]{3}{*}{6} & \multirow{3}{*}{$\begin{array}{l}\text { Tingkat } \\
\text { Pengembalian } \\
\text { Investasi }\end{array}$} & $\operatorname{IRR}(\%)$ & 0,60 & 4 & 2 & 1 \\
\hline & & Payback Period (thn) & 0,40 & 1 & 3 & 5 \\
\hline & & Penilaian akhir & 1,00 & 5 & 1 & 3 \\
\hline \multirow[t]{5}{*}{7} & \multirow{5}{*}{$\begin{array}{l}\text { Safety Alat \& } \\
\text { Lingkungan } \\
\text { Kerja }\end{array}$} & Potensi ledakan (tekanan steam) & 0,25 & 3 & 3 & 1 \\
\hline & & Potensi benda jatuh (dari crane) & 0,25 & 6 & 2 & 1 \\
\hline & & Potensi terpeleset (licin) & 0,25 & 8 & 3 & 1 \\
\hline & & Potensi sabetan tali kawat putus & 0,25 & 6 & 1 & 1 \\
\hline & & Penilaian akhir & 1,00 & 6 & 3 & 1 \\
\hline \multirow[t]{5}{*}{8} & \multirow{5}{*}{$\begin{array}{l}\text { Dampak } \\
\text { Lingkungan }\end{array}$} & Polusi udara (minyak pada udara blowdown) & 0,25 & 6 & 3 & 1 \\
\hline & & $\begin{array}{l}\text { Polusi udara (kandungan partikel dalam asap } \\
\text { cerobong boiler saat peak) }\end{array}$ & 0,25 & 6 & 3 & 1 \\
\hline & & Gangguan suara (kebisingan alat) & 0,25 & 6 & 3 & 1 \\
\hline & & Kebersihan lingkungan kerja & 0,25 & 6 & 3 & 1 \\
\hline & & Penilaian akhir & 1,00 & 6 & 3 & 1 \\
\hline \multirow[t]{3}{*}{9} & \multirow{3}{*}{$\begin{array}{l}\text { Kekinian } \\
\text { Teknologi }\end{array}$} & Kontinyuitas proses & 0,50 & 6 & 4 & 1 \\
\hline & & Otomasi proses & 0,50 & 6 & 4 & 1 \\
\hline & & Penilaian akhir & 1,00 & 6 & 4 & 1 \\
\hline
\end{tabular}

Sumber: Hasil pengolahan data berdasarkan penilaian panel

* konsensus panel berdasarkan fakta dan pengalaman lapangan tentang kontribusi capaian indikator proxy terhadap sub kriteria terkait.

oleh indikator proxy : (1) siklus rebusan, (2) konsumsi listrik, dan (3) konsumsi uap, sehingga berdasarkan data teknis dari indikator proxy ini maka performansi dari ketiga jenis sterilizer dapat dinilai. Contoh untuk indikator konsumsi listrik, dengan kriteria bahwa alat yang mengkonsumsi listrik paling kecil dinilai paling baik, maka panel menilai urutan tingkat prioritas jenis sterilizer

Tabel 6. Matriks perbandingan Sub Kriteria Efisiensi Teknologi

\begin{tabular}{cccc}
\hline Efisiensi Teknologi & $\mathbf{H ~ ( 6 )}$ & $\mathbf{V ~ ( 1 )}$ & $\mathbf{K}(\mathbf{3})$ \\
\hline H (6) & 1 & $1 / 6$ & $3 / 6$ \\
V (1) & 6 & 1 & 3 \\
K (3) & $6 / 3=2$ & $1 / 3$ & 1 \\
\hline
\end{tabular}

berdasarkan pemakaian listrik adalah sterilizer horisontal, sterilizer vertikal, dan sterilizer kontinyu. Selanjutnya data teknis pada Tabel 4 dikonversikan menjadi skala komparasi 1-9, sehingga penilaian performansi masing-masing teknologi urutannya adalah " 1 " untuk sterilizer horizontal, " 2 " untuk sterilizer vertikal, dan "4" untuk sterilizer kontinyu. Penilaian yang sama berlaku untuk indikator proxy yang lain, sehingga panel mengkonversi data alat pada Tabel 4 menjadi data format skala komparasi berpasangan sebagaimana ditunjukkan oleh kolom (5), (6), dan (7) pada Tabel 5.

Derajat pengaruh setiap indikator proxy terhadap sub kriteria hirarki III dapat berbeda, sehingga perlu dilakukan pembobotan. Besarnya bobot merupakan hasil konsensus panel, tetapi 
Tabel 7. Tingkat prioritas lokal untuk seluruh hirarki

\begin{tabular}{|c|c|c|c|c|c|c|c|}
\hline \multirow{2}{*}{$\begin{array}{c}\text { LEVEL } 1 \\
\text { Tujuan }\end{array}$} & \multicolumn{2}{|c|}{ LEVEL II } & \multicolumn{2}{|c|}{ LEVEL III } & \multicolumn{3}{|c|}{$\begin{array}{c}\text { LEVEL IV } \\
\text { (Tingkat Prioritas Model } \\
\text { Sterilizer) }\end{array}$} \\
\hline & Kriteria & Prioritas & Sub Kriteria & Prioritas & Horisontal & Vertikal & Kontinyu \\
\hline \multirow{9}{*}{$\begin{array}{l}\text { Model } \\
\text { Sterilizer } \\
\text { Ideal }\end{array}$} & \multirow{3}{*}{$\begin{array}{l}\text { Performa } \\
\text { alat }\end{array}$} & \multirow[t]{3}{*}{0,582} & Efisiensi Alat & 0,387 & 0,111 & 0,667 & 0,222 \\
\hline & & & $\begin{array}{l}\text { Produk yang } \\
\text { Dihasilkan }\end{array}$ & 0,443 & 0,571 & 0,143 & 0,286 \\
\hline & & & Kepraktisan Alat & 0,169 & 0,143 & 0,571 & 0,286 \\
\hline & \multirow[t]{3}{*}{ Keuangan } & \multirow[t]{3}{*}{0,309} & $\begin{array}{l}\text { Tingkat } \\
\text { Pengembalian } \\
\text { Investasi }\end{array}$ & 0,200 & 0,122 & 0,648 & 0,230 \\
\hline & & & Nilai Investasi & 0,600 & 0,648 & 0,230 & 0,122 \\
\hline & & & Biaya Operasional & 0,200 & 0,143 & 0,286 & 0,571 \\
\hline & \multirow{3}{*}{$\begin{array}{l}\text { Image } \\
\text { Teknologi }\end{array}$} & \multirow[t]{3}{*}{0,109} & Kekinian Teknologi & 0,648 & 0,106 & 0,193 & 0,701 \\
\hline & & & Safety Alat & 0,230 & 0,111 & 0,222 & 0,667 \\
\hline & & & $\begin{array}{l}\text { Dampak } \\
\text { Lingkungan }\end{array}$ & 0,122 & 0,111 & 0,222 & 0,667 \\
\hline
\end{tabular}

Sumber: hasil pengolahan data

magnitude-nya didasarkan atas fakta teknis. Sebagai contoh, pada sub kriteria produk yang dihasilkan, indikator proxy kehilangan minyak (kuantitas) diberi bobot lebih tinggi dibanding kualitas minyak, karena fakta bisnis menunjukkan bahwa dampak dari indikator kuantitas terhadap pendapatan lebih nyata. Dari segi dampak indikator kuantitas, kehilangan minyak dalam tandan kosong diberi bobot paling besar $(0,40)$ karena fakta hasil laboratorium dan neraca bahan menunjukkan bahwa total kehilangan minyak yang terdapat pada tandan kosong paling besar dibanding kehilangan minyak yang terdapat pada air kondensat $(0,3)$, terlebih lagi terhadap kehilangan kernel $(0,1)$.
Penilaian performansi sterilizer dari sudut pandang sub kriteria efisiensi teknologi selanjutnya dilakukan dengan menghitung rata-rata tertimbang dari semua indikator proxy, dengan menormalisasi angka-angka pada kolom (5), (6), dan (7) dengan bobot dari masingmasing indikator proxy (kolom 4), dan hasilnya ditunjukkan pada baris penilaian akhir pada Tabel 5. Angka pada baris penilaian akhir ini menunjukkan penilaian panel untuk performansi masing-masing jenis sterilizer pada masing-masing sub kriteria. Selanjutnya berdasarkan penilaian performansi dari ketiga jenis teknologi tersebut, dilakukan perbandingan berpasangan untuk sub kriteria efisiensi teknologi dan menghasilkan

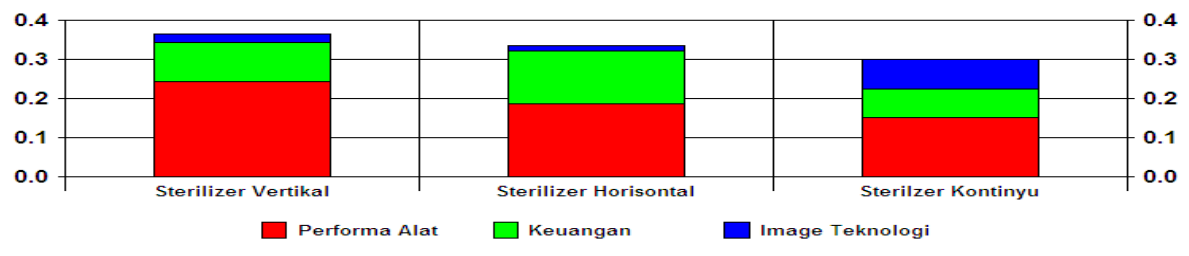

Gambar 6. Kontribusi Kriteria (hirarki II) pada tujuan akhir 


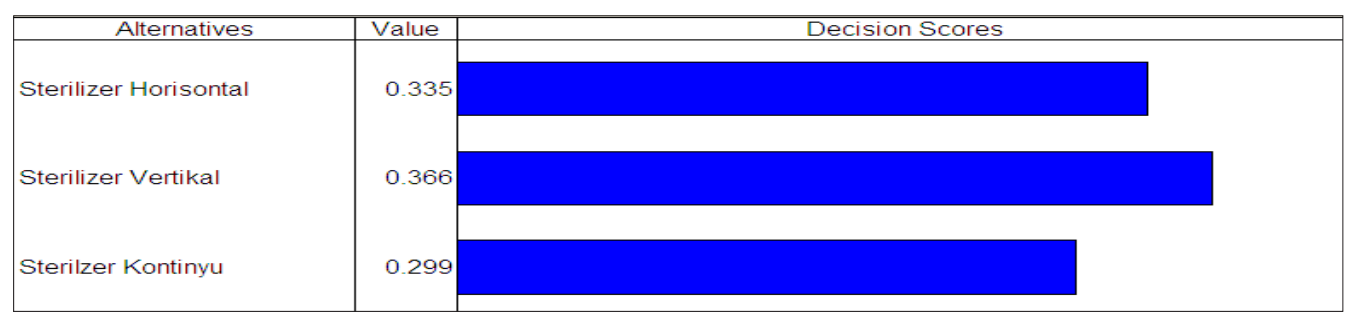

Gambar 8. Diagram tingkat keputusan prioritas model sterilizer

matriks perbandingan sebagaimana ditunjukkan Tabel 6.

\section{Hasil Analisis}

1) Hasil Pengolahan Horisontal

Hasil pengolahan horisontal yang menunjukkan tingkat prioritas elemen pada suatu hirarki (prioritas lokal) terhadap elemen di atasnya secara lengkap disampaikan pada Tabel 7 Pada hirarki II, elemen performa alat mempunyai kontribusi prioritas yang paling kuat $(0,582)$ dalam menentukan model sterilizer yang ideal, dibanding dengan elemen keuangan $(0,309)$ dan image teknologi $(0,109)$. Argumentasinya karena performa alat merupakan kriteria pembeda yang paling relevan untuk perbandingan teknologi dan datanya murni merupakan kondisi objektif alat.

Pada kriteria performa alat, sub kriteria yang paling berpengaruh adalah produk yang dihasilkan $(0,443)$, dibanding dengan efisiensi alat $(0,387)$ maupun kepraktisan alat $(0,169)$. Walaupun semua sub kriteria penting, tetapi nilai output diperhitungkan paling besar dibanding dengan nilai utilitas (energi) maupun nilai penghematan biaya operasi. Selanjutnya pada kriteria keuangan, sub kriteria yang paling berpengaruh adalah beban investasi dengan bonot sebesar 0,6. Sub kriteria yang paling berpengaruh untuk image teknologi adalah kekinian teknologi dengan bobot lokal sebesar 0,648.

Pada jenjang paling bawah, sterilizer model horisontal sangat bagus performansinya ditinjau dari segi produk yang dihasilkan $(0,571)$ dan nilai investasi $(0,648)$, tetapi lemah pada sub kriteria kekinian teknologi, safety alat, dampak lingkungan, efisiensi alat, dan biaya operasional (perawatan lori). Sementara itu, sterilizer model vertikal memiliki performansi yang bagus pada sub kriteria efisiensi alat, tingkat pengembalian, dan kepraktisan alat, tetapi lemah pada sub kriteria produk yang dihasilkan. Sedangkan sterilizer model kontinyu, memiliki performansi yang bagus pada sub kriteria kekinian teknologi, safety alat, dampak lingkungan dan biaya operasional, tetapi lemah pada sub kriteria beban investasi, tingkat pengembalian, dan efisiensi alat.

2) Hasil Pengolahan Vertikal

Distribusi tingkat pengaruh kumulatif kriteria pada hirarki II terhadap hasil/keputusan akhir ditunjukkan pada Gambar 6. Berdasarkan Gambar 6, terlihat bahwa kontributor terbesar yang mengantarkan sterilizer model vertikal

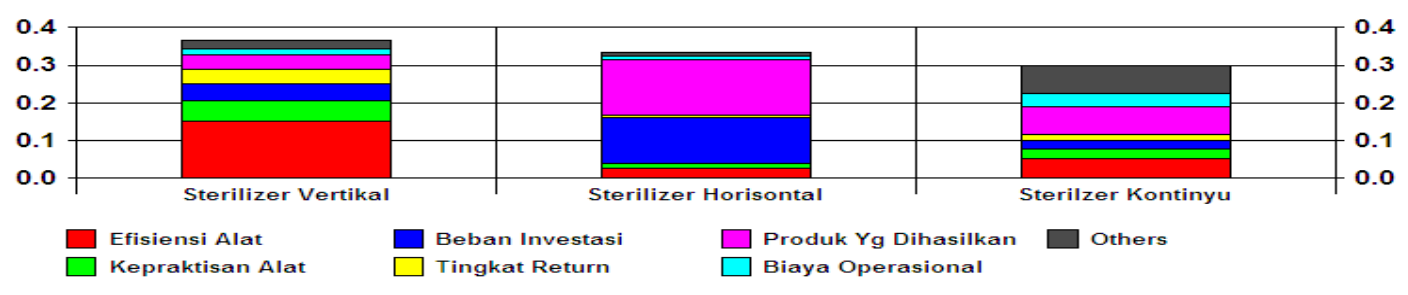

Gambar 7. Kontribusi sub kriteria (hirarki III) pada tujuan akhir 
kepada prioritas tertinggi adalah kriteria performa alat yang didukung selanjutnya oleh kriteria keuangan. Sementara itu sterilizer model horisontal menonjol pada kriteria keuangan dibanding dengan dua model yang lain, tetapi sangat lemah pada image teknologi. Sedangkan sterilizer kontinyu sangat dominan pada kriteria image teknologi dibanding dengan dua model yang lain, tetapi pengaruh kriteria performa teknologi dan keuangan paling lemah dibanding dengan dua model lainnya.

Distribusi tingkat pengaruh kumulatif sub kriteria pada hirarki III terhadap hasil/keputusan akhir ditunjukkan pada Gambar 7. Pada hirarki III, pengaruh sub kriteria efisiensi alat sangat dominan dalam menentukan sterilizer yang ideal, dan kondisi ini muncul dominan pada sterilizer model vertikal. Berdasarkan hasil survey, sterilizer model vertikal yang menggunakan model single peak paling hemat dalam penggunaan steam, yaitu sekitar $350 \mathrm{~kg} /$ ton TBS, dibanding dengan model horisontal atau model kontinyu yang konsumsi steam-nya di atas $500 \mathrm{~kg} /$ ton TBS. Siklus rebusan yang dimiliki juga relatif pendek, yaitu sekitar 90 menit. Di samping itu sterilizer vertikal juga unggul pada sub kriteria kepraktisan alat, karena pengoperasiannya dipermudah dengan otomasi transportasi tandan buah dan model buka/tutup alat sterilizer, sementara tingkat kerusakan yang muncul bisa dengan cepat diperbaiki oleh teknisi internal. Hasil perhitungan juga menunjukkan bahwa pengaruh kombinasi antara data Internal Rate of Return (IRR) dan Payback Period telah memberikan intensitas efek prioritas sub kriteria tingkat pengembalian yang lebih dominan pada PKS yang menggunakan sterilizer vertikal dibanding dengan model horisontal maupun kontinyu.

Produk yang dihasilkan dan efisiensi alat merupakan sub kriteria yang pengaruhnya dominan dalam menentukan hasil akhir pemilihan model sterilizer. Kontribusi sub kriteria ini sangat dominan pada sterilizer horisontal. Begitu juga sub kriteria nilai investasi, khususnya nilai pengadaan alat yang paling rendah, pengaruhnya cukup dominan pada sterilizer horisontal. Walaupun demikian sterilizer horisontal kurang didukung oleh sub kriteria lain sehingga secara keseluruhan tingkat prioritas kumulatifnya masih di bawah sterilizer vertikal, tetapi masih di atas sterilizer kontinyu.

Berdasarkan tingkat pengaruh kumulatif dari kriteria dan sub kriteria pada hirarki II dan III, maka hasil pengolahan vertikal yang melibatkan seluruh hirarki menghasilkan tingkat keputusan final dalam menjawab tujuan akhir, yaitu penetapan model sterilizer yang ideal. Keputusan final tersebut menunjukkan bahwa urutan tingkat prioritas untuk alat sterilizer adalah model vertikal dengan tingkat prioritas sebesar 0,338 , kemudian diikuti dengan model horisontal $(0,335)$ dan model kontinyu $(0,299)$ seperti ditunjukkan pada Gambar 8.

\section{SIMPULAN}

Hasil analisis pemilihan teknologi menggunakan metode AHP menyimpulkan bahwa sterilizer model vertikal mempunyai tingkat prioritas yang paling tinggi $(0,366)$, dibanding model horisontal $(0,335)$ dan kontinyu $(0,299)$. Berdasarkan metode analisis yang digunakan, pemilihan jenis alat rebusan TBS mengarah kepada sterilizer vertikal, karena keunggulannya pada kriteria performa alat, khususnya efisiensi alat. Hasil akhir tingkat prioritas model alat dipengaruhi oleh kebijakan strategi bisnis perusahaan, khususnya oleh tim penilai dalam memberikan bobot teknologi pada variabel strategis. Karena itu manajemen puncak perlu aktif terlibat dalam memberikan penilaian.

\section{DAFTAR PUSTAKA}

Abu S., Abd Manaf, L., Aris, A.Z. and Sulaiman, W.N.A., 2011. Solid Waste Management: Analytical Hierarchy Process (AHP) Application of Selecting Treatment Technology in Sepang Municipal Council Malaysia, Journal of Current World Environment. 6 (1), 1-16.

Ahmadabadi, M.N., Najafi, M., Peyman Gholami, and Payam Gholami, 2013. Using Analytic Hierarchy Process (AHP) to Select and Rank a Strategy Based Technology, International Journal of Computer Science and Business Informatics, 4 (1). 
Al-Hawari, T., Al-Bo'ol, S., and A. Momani, A., 2011. Selection of Temperature Measuring Sensors Using the Analytic Hierarchy Process, Jordan Journal of Mechanical and Industrial Engineering, 5 (5), 451-459.

Awan T., 2012. Leading Palm Oil Mill Technology Innovator. Video Expose Company No. 417234T. Sdn Bhd.

Badan Penelitian dan Pengembangan Pertanian, 2005. Prospek dan Arah Pengembangan Agribisnis Kelapa Sawit Indonesia, Departemen Pertanian, Jakarta.

Bisnis Indonesia, 31 Desember 2011. Saatnya RI Menentukan Harga CPO Dunia, Edisi Harian.

CDMI Consulting Group, 2013. Studi Potensi Bisnis dan Pelaku Utama Industri CPO di Indonesia 2014-2017, PT. Central Data Mediatama Indonesia, Jakarta.

Dewan Minyak Sawit Indonesia (DMSI), 2008. Industri dan Perdagangan Minyak Sawit, Jakarta.

CHD Engineering, 2009. CHD Vertical Sterilizer (leaflet/prospektus), Sdn. Bhd.

Ditjen Perkebunan, 2012. Pembangunan Pabrik Kelapa Sawit Untuk Meningkatkan Produksi CPO, URL:http//www.ditjenbun@deptan.go.id.

Fibrian, D. C., Sri M., dan Marimin, 2011. Sistem Penunjang Keputusan Untuk Optimalisasi Pemanfaatan Limbah Padat Kelapa Sawit, Jurnal Teknologi Industri Pertanian, 20 (2), 130-142.

Fadli H., 2014. Refleksi Industri Kelapa Sawit 2013 dan Prospek 2014, GAPKI, Jakarta URL: http:/ www.gapki.or.id/.

Hadiguna, R.A., 2012. Model Penilaian Risiko Berbasis Kinerja untuk Rantai Pasok Kelapa Sawit Berkelanjutan di Indonesia, Jurnal Teknik Industri, 14 (1), 13-24.

Hidayat, M., Ani S., Sukardi, dan Mohamad Yani, 2012. Model Identifikasi Risiko dan Strategi Peningkatan Nilai Tambah pada Rantai Pasok Kelapa Sawit. Jurnal Teknik Industri, 14 (2), 89-96.

Kim, W., 2012. Reverse Analytic Hierarchy Process (AHP) to Prioritize Emerging IT Technologies: A Case Study in Korea IT Industry, African Journal of Business Management, 6 (24), 7214 7229.

Moengin, P., 2013. Model AHP/DEA untuk Mengukur Efisiensi Penggunaan Teknologi Gas Buang Rumah Tangga Ramah Lingkungan. J@TI Undip, VIII (1).
Montenegro, LV., Amparo Baviera-Puig, A.B., and Álvarez-Coque, J.M.G., 2014. Multi-Criteria Methodology: AHP and Fuzzy Logic in the Selection of Post-Harvest Technology for Smallholder Cocoa Production, International Food and Agribusiness Management Review,17 (2).

Moreno-Jiménez, J.P., Arcocha, D., Arcocha, Emilio Larrodé, E., and Muerza, V., 2012. An AHP Multicriteria Selection Of Products in Industrial and Technological Diversification Strategies, Proceedings of the EWG-DSS Workshop on Decision Support Systems \& Operation Management Trend and Solution in Industries, Liverpool, United Kingdom.

Oil World, 2010. Oil World Annual 2010. World Summary Tables, Comodity Section, Country Section, Indonesia. ISTA Mielke GmbhH, Langenberg Hamburg-Germany.

PTPN IV, 2010. Studi Kelayakan Penggunaan Teknologi Vertical Sterilizer di PTPN IV (Persero), Laporan (tidak dipublikasikan), Medan.

Pahan, I., 2007. Panduan Lengkap Kelapa Sawit: Manajemen Agribisnis dari Hulu hingga Hilir, Penebar Swadaya, Jakarta.

Radjagukguk, J., 2009. Gambaran Kecelakaan Kerja Pada Pekerja Pabrik Pengolahan Kelapa Sawit PTPN IV Kebun Bah Jambi Tahun 20062008, Skripsi, Fakultas Kesehatan Masyarakat Universitas Sumatera Utara, Medan.

Subiyanto, 2011. Pemetaan Teknologi Industri Kelapa Sawit Nasional, Jurnal Ilmiah Sain dan Teknologi - BPPT, Penerbit BPPT Pres, Jakarta.

Saaty, T.L., 1993. Pengambilan Keputusan Bagi Para Pemimpin: Proses Hirarki Analitik untuk Pengambilan Keputusan dalam Situasi yang Kompleks, PT Pustaka Binaman Pressindo, Jakarta.

Saaty, T.L., 2008. Decision Making with The Analytic Hierarchy Process, Int. J. Services Sciences, $1(1)$.

Siew, W., 2012. Palm Oil Milling Process, Malaysian Palm Oil Board, Kuala Lumpur, Malaysia.

Sia, T. T., 2009. Cost Reduction Strategies in Palm Oil Milling Process \& Maintenance, Proceeding The XVI International Oil Palm Conference and Expopalma, Cartegena de Indias, Columbia.

Sitepu, T., 2011. Analisa Kebutuhan Uap pada Sterilizer Pabrik Kelapa Sawit dengan Lama Perebusan 90 Menit, Jurnal Dinamis, II (8). 